\title{
PENINGKATAN AKTIVITAS BELAJAR DAN KEMAMPUAN MEMBACA TEKS EKSPLANASI MELALUI MODEL INSIDE OUTSIDE CIRCLE SISWA KELAS VIII-F SMP NEGERI 1 MOJOANYAR
}

\author{
INAWATI \\ SMP NEGERI 1 MOJOANYAR MOJOKERTO \\ inaawati111@gmail.com
}

\begin{abstract}
Reading ability of explanation text of grade VIII SMP students did not fulfill the MMC. The students were less enthusiastic in reading comprehension. Moreover, the learning method was still fetched up all standing in lecturing method. The students were passive, they just listened to what the teacher delivered. This fact encouraged teachers to develop the learning methods which stimulated students' interest in reading explanation text. The researcher made serious effort to apply the Inside Outside Circle learning model. The aim was to improve learning activities and reading ability of explanation text. The object of this research was the eighth grade students of SMP Negeri 1 Mojoanyar Mojokerto. The method in this study used two cycles, each cycle consisting of four stages, namely planning, implementing, observing, and reflecting. The research instrument used tests and non-tests. The results of the study in the Inside Outside Cicle model were: (1) the average level of learning activity was $60.00 \%$ (quite active category), to $86.88 \%$ (active category), an increase of $26.88 \%$, (2) the average value -The class average of 72.53 becomes 77.69, an increase of 7.57\%, (3) students whose grades are low, there is an increase in the value of $30.43 \%$, (4) the number of students who achieve very good reading skills increases by $3.13 \%$, ( 5) completeness of student learning increased $21.88 \%$. From this, it can be seen that there is an increase in student learning activities from being less active in reading to being more active. Meanwhile, the increase in reading skills can be seen from the increase of test scores. Thus the application of the Inside Outside Circle learning model can improve learning activities and reading ability of Explanation text.

Keywords : Learning activities, Reading ability of Explanation Text, Inside Outside Circle Learning Model
\end{abstract}

\begin{abstract}
Abstrak: Kemampuan membaca teks Eksplanasi siswa SMP kelas VIII belum memenuhi KKM. Siswa kurang bergairah dalam membaca pemahaman . Apalagi metode pembelajaran masih terpaku metode ceramah. Siswa bersikap pasif , hanya mendengarkan yang disampaikan guru. Kenyataan ini mendorong guru mengembangkan metode pembelajaran yang dapat merangsang siswa tertarik membaca Teks Eksplanasi. Penulis berupaya menerapkan model pembelajaran Inside Outside Circle. Tujuannya adalah untuk meningkatkan aktivitas belajar dan kemampuan membaca teks Eksplanasi. Objek penelitian ini adalah siswa kelas VIII SMP Negeri 1 Mojoanyar Mojokerto. Metode dalam penelitian ini menggunakan dua siklus, masing-masing siklus terdiri empat tahap yaitu perencanaan, pelaksanaan, pengamatan, dan refleksi. Instrumen penelitian menggunakan tes dan nontes. Hasil penelitian pembelajaran model Inside Outside Cicle : (1) rata-rata tingkat aktivitas belajar sebesar $60,00 \%$ (kategori cukup aktif), menjadi 86,88\% (kategori aktif), terjadi kenaikan $26,88 \%$, (2) nilai rata-rata kelas 72,53 menjadi 77,69 naik 7,57\%,(3) siswa yang nilainya rendah , ada peningkatan nilai $30,43 \%$,(4) jumlah siswa yang meraih kemampuan membaca amat baik meningkat $3,13 \%$,(5) ketuntasan belajar siswa meningkat sebesar $21,88 \%$. Dari sini terlihat adanya peningkatan aktivitas belajar siswa dari yang kurang aktif membaca menjadi lebih aktif. Sedangkan dalam peningkatan kemampuan membaca terlihat dari meningkatnya nilai ulangan. Dengan demikian penerapan model pembelajaran Inside Outside Circle dapat meningkatkan aktivitas belajar dan kemampuan membaca teks Eksplanasi.

Kata kunci : Aktivitas belajar, Kemampuan Membaca Teks Eksplanasi, Model Pembelajaran Inside Outside Circle.
\end{abstract}




\section{Pendahuluan}

Dalam materi pelajaran Bahasa Indonesia terdapat membaca, menyimak, berbicara, dan menulis. Dari berbagai pengajaran tersebut, membaca merupakan pelajaran yang mudah. Namun pada kenyataannya justru membaca menjadikan hal yang tidak mudah bahkan menjadi beban yang luar biasa, apalagi membaca yang membutuhkan pemahaman. Padahal kunci sukses seseorang adalah dari membaca.

Demikian juga kegiatan pengajaran Bahasa Indonesia yang dilaksanakan di kelas VIII pada dasarnya adalah untuk mencapai kemampuan yang harus dimiliki perserta didik dalam mata pelajaran tertentu. Salah satu yang harus dimiliki oleh siswa kelas VIII semester ganjil adalah

Mengidentifikasi informasi dari teks ekplanasi berupa penjelasan kejadian alam yang didengar atau dibaca dan (2) Meringkas isi teks eksplanasi yang berupa proses terjadinya suatu fenomena dari berbagai sumber yang didengar dan dibaca. Kompetensi dasar ini dapat tercapai melalui kegiatan pembelajaran mengkaji referensi, mengidentifikasikan, mendiskusikan, dan menganalisis materi tentang membaca teks eksplanasi

Namun kenyataannya materi pokok membaca teks eksplanasi, ternyata masih memperlihatkan hasil yang kurang memuaskan yaitu perolehan nilai rerata sebesar 67,22 masih di bawah ketentuan nilai minimal Bahasa Indonesia yang telah ditentukan. Dan jumlah siswa yang berhasil memperoleh nilai sesuai ketentuan hanya sejumlah 11 anak atau $34,38 \%$ berarti keberhasilan belajar dalam kelas belum tercapai karena 85 persen dari jumlah anak belum memperoleh nilai yang ditentukan .

Berdasarkan hasil refleksi diri antara peneliti dengan teman sejawat diketahui ada sejumlah komponen yang menyebabkan keterampilan membaca masih kurang, yaitu : (1) guru masih terpaku pada penerapan teknik pembelajaran ceramah sehingga kegiatan belajar lebih terpusat pada guru dan kurang mengikutsertakan anak untuk aktif dalam kegiatan belajar.

Dengan demikian melalui penerapan metode konvensional, materi yang diberikan masih bersifat verbal, yang mengakibatkan materi sulit untuk dicerna dan dipahami bahkan lebih bersifat verbal, (2) guru kurang memberi dorongan kepada siswa untuk bertanya maupun menjawab, biasanya langsung dijawab sendiri oleh guru tanpa melibatkan siswa dan siswa sendiri hanya disuruh mendengarkan serta menyimak isi materi tersebut, (3) kebanyakan kata-kata yang sulit dalam wacana teks eksplanasi langsung diartikan oleh guru sendiri dengan alasan agar segera selesai dan target kurikulum tercapai, (4) banyak anak yang tidak siap untuk ikut dalam kegiatan belajar , sebab mereka belum tahu materi apa yang akan diberikan oleh guru sehingga mereka belum siap pertanyaan yang harus dilontarkan, (5) situasi pembelajaran kurang menyenangkan yang berakibat siswa cepat bosan dan mudah ngantuk serta kurang termotivasi, (6) siswa masih takut dan malu untuk membaca teks eksplanasi serta mengemukakan pendapat ataupun mengajukan pertanyaan, (7) banyak siswa yang tidak membawa kamus Bahasa Indonesia dalam mengikuti pembelajaran Bahasa Indonesia sehingga mereka mengalami kesulitan dalam mengartikan kata-kata penting dalam bacaan teks eksplanasi dan (8) guru kurang mengkaitkannya materi membaca eksplanasi dengan kehidupan nyata sehari-hari, sehingga pembelajaran membaca lebih bersifat abstrak.

Hal ini akan berdampak pada rendahnya tingkat daya serap/ 
kemampuan membaca. Oleh karena itu penanganan masalah rendahnya tingkat aktivitas/peran serta langsung siswa dalam mengikuti pembelajaran sangat mendesak untuk dicari solusinya

Dari bermacam penyebab rendahnya tingkat aktivitas belajar dan kemampuan membaca teks eksplanasi siswa, tentunya penulis tidak mampu untuk memperbaiki semuanya secara bersamaan, sehingga penulis memilih memperbaiki salah satu aspek saja yaitu aspek model pembelajaran. Model pembelajaran yang dipilih sebagai jalan keluar dari permasalahan tersebut yaitu metode belajar Inside Outside Circle.

\section{Metode}

A.Subjek penelitian

Subjek penelitian ini siswa kelas VIII SMP Negeri 1 Mojoanyar yang berjumlah 32 siswa, laki-laki 14 siswa perempuan dan 18 .

\section{B. Rancangan Penelitian}

Penelitian ini dirancang dalam 2 (dua) siklus. Masing-masing siklus dilaksanakan dalam 4 (empat) tahap yaitu perencanaan,pelaksanaaan tindakan, pengamatan dan refleksi. Kemudian siklus I dilaksanakan dalam 4 jam pelajaran $(2 \mathrm{x}$ pertemuan) dan siklus II juga dilaksanakan dalam 4 jam pelajaran ( $2 \mathrm{x}$ pertemuan).

\section{Putaran kesatu}

a. Langkah Persiapan

Peneliti menyusun rancangan kelengkapan alat mengajar berupa Silabus, RPP, LKS dan instrumen penelitian berupa ulangan tulis bentuk pilihan jawaban dan uraian untuk mengukur tingkat kemampuan membaca siswa tentang teks eksplanasi dan nontes berupa pedoman pengamatan, angket, catatan lapangan dan dokumentasi untuk mengukur tingkat keaktifan belajar siswa.

b. Langkah Pelaksanaan

Pelaksanaan tindakan

dilakukan pada bulan Oktober 2018

minggu kedua semester ganjil tahun pelajaran 2018/2019 selama 4 jam (2 $\mathrm{x}$ tatap muka). Kegiatan pembelajaran dilaksanakan dalam 2 (dua) kali pertemuan.

c. Langkah Peninjauan

Peninjauan dilaksanakan selama proses pembelajaran yang menerapkan model Inside Outside Circle berlangsung, yang dilaksanakan oleh kolaborator dengan menggunakan alat pengumpulan hasil catatan pengamatan. Peninjauan dilaksanakan untuk melihat secara teliti kegiatan guru dan murid dalam kegiatan belajar mengajar dengan cara mengisi cek list yang telah disediakan.

\section{d. Langkah Refleksi}

Langkah ini dilaksanakan setelah kegiatan proses pembelajaran dalam putaran I selesai. Data hasil tes dan hasil catatan pengamatan selama proses pembelajaran yang menerapkan model Inside Outside Circle digunakan untuk menunjang kegiatan kilas balik. Hal ini dilakukan untuk mengetahui berhasil tidaknya penelitian tindakan kelas tentang aktivitas belajar siswa meningkat ataukah tidak dan apakah kemampuan membaca siswa meningkat ataukah tidak. Bila dalam putaran kesatu tidak berhasil maka akan dilanjutkan pada siklus berikutnya.

\section{Putaran kedua}

a. Langkah Persiapan

$$
\text { Pada langkah ini peneliti }
$$
menyusun rancangan mengajar berupa Silabus, RPP, LKS, dan 
instrument tes bentuk uraian untuk mengukur tingkat kemampuan membaca siswa tentang teks eksplanasi dan nontes berupa pedoman pengamata, angket, catatan lapangan dan dokumentasi untuk mengukur tingkat keaktifan belajar siswa.

b. Langkah Pelaksanaan

Pelaksanaan tindakan dilakukan pada bulan Oktober 2018 minggu ketiga semester ganjil tahun pelajaran 2018/2019 selama 4 jam pelajaran ( $2 \mathrm{x}$ pertemuan).

c. Langkah Pengamatan

Pengamatan dilaksanakan selama proses pembelajaran yang menerap model Inside Outside Circle , yang dilaksanakan oleh kolaborator dengan menggunakan alat pengumpulan data catatan pengamatan. Pengamatan ini dilaksanakan untuk meneliti peneliti dan murid dalam proses pembelajaran dengan mengisi cek list.

d. Langkah Refleksi

Langkah ini dilaksanakan setelah kegiatan proses pembelajaran dalam putaran kesatu selesai dan kegiatan ini dilakukan oleh peneliti yang dibantu kolaborator. Data hasil tes dan hasil catatan pengamatan selama proses pembelajaran yang menerapkan Inside Outside Circle digunakan untuk menunjang kegiatan refleksi. Hal ini dilakukan untuk mengetahui berhasil tidaknya peneletian ini yaitu apakah aktivitas belajar siswa meningkat atau tidak dan apakah kemampuan membaca siswa juga meningkat atau tidak. Mengingat dalam putaran kedua ternyata telah berhasil maka percobaan ini hanya sampai pada putaran kedua.

\section{Perangkat Penelitian}

Perangkat ini disusun untuk memperoleh data yaitu berupa ulangan dan bukan ulangan (petunjuk pengamatan, daftar pertanyaan, tulisan hasil kegiatan dan pengarsipan gambar kegiatan). Perangkat ulangan berbentuk soal pilihan jawaban dan soal jawaban pertanyaan objektif. Perangkat ulangan dikerjakan murid sesuai perintah. Ulangan dilakukan saat pertemuan kedua dalam putaran pertama.

Selanjutnya petunjuk pengamatan disusun guna menjaring perolehan hasil aktivitas murid pada saat mengikuti kegiatan belajar dengan model belajar Inside Outside Circle.

Perangkat daftar pertanyaan dipakai untuk menjaring hasil perolehan kegiatan belajar siswa selama mengikuti proses belajar yang menggunakan cara Inside Outside Circle yang dikerjakan saat kegiatan belajar akan berakhir, sehingga tidak akan mengganggu jalannya pelajaran.

Perangkat catatan hasil kegiatan digunakan untuk menjaring data penguat kejadian-kejadian yang dapat mempengaruhi pelaksanaan belajar dengan teknik Inside Outside Circle.

Perangkat pengarsipan merupakan kegiatan menghimpun hasil foto murid pada saat mengikuti proses belajar yang menggunakan teknik Inside Outside Circle. Kegiatan pengarsipan foto dilaksanakan oleh kolaborator.

\section{Cara Pengumpulan Data}

Perolehan hasil kegiatan selama mengikuti pelajaran dengan metode Inside Outside Circle bisa dihimpun dari pengisian petunjuk pengamatan, tulisan hasil kegiatan, pengisian daftar pertanyaan dan pengarsipan gambar kegiatan. Sedangkan data tingkat 
kemampuan membaca siswa tentang teks eksplanasi dapat dihimpun dari hasil ulangan siswa.

\section{E. Cara Analisis Data}

Langkah-langkah kegiatan ini , sebagai berikut :

1. Pengarsipan dan pengolahan data.

Yaitu kegiatan memeriksa kembali semua bahan masukan yang terkumpul dan menyeleksi yang salah selanjutnya mengklasifikasikan dan memberi tanda-tanda untuk keperluan tabel dan telaah.

2. Menstabulasi data untuk ditelaah.

Adalah kegiatan menyusun data yang berupa bagan/grafik. Pada langkah ini dilaksanakan pemberian nilai, penggantian jenis data yang dibutuhkan sesuai tujuan percobaan.

3. Menelaah dan mengklarifikasi data sesuai tujuan.

Adalah kegiatan melaksanakan pengujian yang memakai telaah catatan angka-angka yang cocok dengan macam data dan tujuan telaahnya.

Analisis data dilakukan dengan cara telaah data paparan kuantitatif. Patokan yang dipakai mengolah dan menelaah bahan adalah yang berasal dari ulangan yang dapat ditelaah dengan tindakan:

a. Mengkategorikan tingkat aktivitas belajar siswa melalaui beberapa indikator. Dari indikator tersebut maka dapat dikategorikan tingkat belajar siswa dengan jalan menstabulasi data hasil angket siswa yaitu :

Jumlah nilai tertinggi $=$

10 item $\times 1=10$ nilai

Jumlah nilai terendah $=$

10 item $\times 0=0$ nilai

Selisih $=10$ skor.

Interval kelas $=10: 5=2$
Tabel 1. Interpretasi tingkat aktivitas belajar siswa secara individual

\begin{tabular}{|l|l|}
\hline Interval kelas & Kategori interpretasi \\
\hline $9-10$ & Aktif \\
\hline $7-8$ & Cukup Aktif \\
\hline $5-6$ & Kurang aktif \\
\hline $3-4$ & Rendah \\
\hline$\leq 2$ & Sangat rendah \\
\hline
\end{tabular}

Tabel 2. Interpretasi tingkat aktivitas belajar siswa secara kumulatif

\begin{tabular}{|l|l|}
\hline $\begin{array}{l}\text { Interval } \\
\text { kelas }\end{array}$ & Kategori interpretasi \\
\hline $81-100$ & Aktif \\
\hline $61-80$ & Cukup Aktif \\
\hline $41-60$ & Kurang aktif \\
\hline $21-40$ & Rendah \\
\hline$\leq 20$ & Sangat rendah \\
\hline
\end{tabular}

b. Mencari tingkat kemampuan membaca siswa secara individu.

Peneliti mengoreksi hasil tes/ lembar jawaban siswa dengan memberi skor.. Langkah berikutnya skor dikonversikan menjadi nilai. Dari sinilah maka dapat diketahui tingat kemampuan membaca siswa.

Tabel 3. Nilai jawaban putaran kesatu dan kedua

\begin{tabular}{|l|c|c|c|}
\hline $\begin{array}{l}\text { Bentuk } \\
\text { Soal }\end{array}$ & $\begin{array}{c}\text { Nomor } \\
\text { soal }\end{array}$ & $\begin{array}{c}\text { Bob } \\
\text { ot } \\
\text { nilai }\end{array}$ & $\begin{array}{l}\text { Jumlah } \\
\text { Nilai }\end{array}$ \\
\hline $\begin{array}{c}\text { pilihan } \\
\text { ganda }\end{array}$ & 1 s.d.10 & 4 & 40 \\
\hline uraian & $\begin{array}{c}11 \text { s.d. } \\
15\end{array}$ & 12 & 60 \\
\hline \multicolumn{2}{|l|}{ Jumlah Total } & 100 \\
\hline
\end{tabular}

c. Mencari tingkat kemampuan membaca siswa secara kumulatif dengan rumus rata-rata ( Mean )

$$
\text { Rumusnya }: X=\frac{\sum \text { nilai }}{\sum \text { siswa }}
$$


Patokan ini dipakai menganalisis perolehan hasil ulangan untuk mengetahui angka rata-rata kemampuan membaca. Supaya telaah datanya dapat dipaparkan secara kualitatif maka dapat dijelaskan dengan tabel berikut ini:

Tabel 4. Tabel interpretasi tingkat kemampuan membaca tentang teks eksplanasi

\begin{tabular}{|l|l|}
\hline Interval kelas & $\begin{array}{l}\text { Interpretasi tingkat } \\
\text { kemampuan membaca } \\
\text { tentang teks eksplanasi }\end{array}$ \\
\hline $91-100$ & Sangat bagus \\
\hline $75-90$ & Bagus \\
\hline $60-74$ & Cukup \\
\hline $40-59$ & Kurang \\
\hline$<40$ & Sangat kurang \\
\hline
\end{tabular}

Bagan ini untuk menjelaskan bahan perolehan ulangan untuk mengelompokkan tingkat kemampuan membaca teks eksplanasi.

d. Mencari prosentase (\%)

ketuntasan belajar klasikal

Rumus mencari ketuntasan

belajar klasikal

$=\sum$ siswa yang tuntas $\times 100 \%$

$\sum$ seluruh siswa

Patokan ini dipakai untuk menelaah bahan perolehan ulangan supaya tingkat keberhasilan belajar secara menyeluruh dapat diketahui. Dalam hal ini KKM Bahasa Indonesia 75.

Selanjutnya data yang berasal dari catatan lapangan, pengisisan pedoman pengamatan dan angket dianalisis dengan cara deskriptif kuantitatif. Untuk mengukur keberhasilan penelitian dapat dilakukan dengan tabel berikut :
Tabel 5. Indikator kriteria keberhasilan penelitian

\begin{tabular}{|c|l|}
\hline No & \multicolumn{1}{|c|}{ Kriteria keberhasilan } \\
\hline 1 & $\begin{array}{l}\text { Tingkat aktivitas belajar tinggi } \\
\text { (rata-rata } \geq 80 \%)\end{array}$ \\
\hline 2 & $\begin{array}{l}\text { Ketuntasan belajar klasikal } \\
\text { mencapai } 85 \%\end{array}$ \\
\hline 3 & Rata-rata KKM 75 \\
\hline
\end{tabular}

\section{Hasil dan Pembahasan}

Sebagai langkah awal peneliti memperkenalkan model pembelajaran Inside Outside Circle. Kemudian peneliti merencakanan kegiatan yang akan dilaksanakan tentang beberapa hal penting antara lain : (a) materi yang akan digunakan dalam penelitian adalah membaca teks eksplanasi, (b) pelaksanaan tindakan disesuaikan dengan jadwal pelajaran, (c) guru merangkap sebagai peneliti dan pemberi respon sedangkan teman sejawat sebagai pengamat yang membantu peneliti dalam meneliti kegiatan belajar dengan metode Inside Outside Circle.

Pada pendahuluan dilakukan pengamatan dengan maksud untuk mengetahui tingkat penangkapan anak terhadap materi membaca teks eksplanasi.

Melalui kegiatan observasi pendahuluan ini diperoleh data awal dari hasil tes yang kemudian ditelaah guna mengetahui tingkat pemahaman murid tentang kemampuan mengidentifikasi informasi teks eksplanasi. Data yang diperoleh adalah seperti berikut:

1) Telaah data hasil daftar pertanyaan diketahui rerata tingkat aktivitas/ peran serta murid saat kegiatan belajar sebesar $60,00 \%$, masuk adalam kategori kurang aktif.

2) Dari perolehan telaah data putaran kesatu diketahui bahwa nilai rerata kelas sebesar 67,22. Rerata ini masih jauh dibawah kriteria ketuntasan minimal Bahasa Indonesia sebesar 75. Nilai tertinggi yang diperoleh murid 
sebesar 78, dan nilai terendah yang diperoleh murid sebesar 44 .

3) Berdasarkan telaah data tingkat penguasaan materi membaca teks eksplanasi ternyata belum berhasil, karena murid yang bisa memperoleh peringkat kemampuan membaca sangat bagus (nilai 91-100), 11 anak atau $34,38 \%$ yang mampu mencapai peringkat kemampuan membaca tentang teks eksplanasi baik (nilai 75-90), 16 siswa atau 50,00\% yang mampu mencapai peringkat kemampuan membaca cukup (nilai 60-74), 5 siswa atau $15,62 \%$ yang mencapai peringkat kemampuan membaca kurang (nilai 40 - 59) dan tidak ada siswa yang mencapai peringkat kemampuan membaca kurang sekali $(<40)$.

4) Berdasarkan hasil analisis data jumlah siswa yang tuntas baru mencapai 13 anak atau $34,78 \%$, masih jauh dari keberhasilan belajar secara menyeluruh yaitu $85 \%$ dari jumlah murid yang telah menyelesaikan standar nilai yang ditetapkan. Sehingga hasil penelitian putaran kesatu menunjukkan kualitas pembelajaran dan kemampuan membaca teks eksplanasi belum ada peningkatan.

\section{Putaran kedua}

1) Telaah data hasil daftar pertanyaan diketahui rerata aktivitas peran serta murid dalam kegiatan belajar sebesar 86,88\%, dikelompokkan bahwa tingkat kegiatan siswa dalam belajar tergolong aktif.

2) Berdasarkan analisis data diketahui bahwa angka perolehan rerata kelas sebesar 77,69, nilai ini sudah berada diatas ketentuan ketuntasan minimal. Angka tertinggi yang diperoleh murid 92 dan angka terendah yang diperoleh murid sebesar 60.

3) Berdasarkan analisis data tingkat penguasaan materi atau tingkat kemampuan membaca teks Eksplanasi yang diraih murid kenyataannya sudah ada 1 orang atau $3,13 \%$ yang mampu memperoleh ranking baik sekali ( nilai 91_100), 27 orang nilainya 84,37 dengan kriteria baik ( nilai $75-90$ ), 4 orang $12,50 \%$ dengan kriteria cukup ( nilai 60-74), dan tidak ada siswa yang mencapai nilai kurang ( nilai 40-50) serta tidak ada yang peringkat kurang sekali ( nilai kurang dari 40).

4) Berdasarkan analisis data, total anak yang berhasil sudah 28 orang $187,50 \%$ dan sudah memperoleh keberhasilan belajar secara menyeluruh yaitu $85 \%$ dari jumlah anak yang memperoleh ketentuan nilai yang ditetapkan yaitu 75 .

5) Berdasarkan hasil pemantauan dan telaah data hasil ulangan, ternyata (1) angka rerata kelas sebesar 77,69, angka rerata ini sudah berada di atas kriteria minimal, (2) sudah ada 1 orang atau $3,13 \%$ yang dapat meraih peringkat amat baik, dan (3) total anak yang tuntas sudah 28 orang $187,50 \%$ dan sudah memperoleh ketuntasan klasikal dari jumlah siswa.

Dengan demikian berdasarkan hasil telaah data putaran kedua telah diketahui adanya peningkatan yang optimal mutu pembelajaran dan kemampuan membaca teks eksplanasi serta telah memenuhi indeks keberhasilan penelitian. Sehingga penelitian tindakan kelas ini hanya sampai putaran kedua.

\section{Simpulan}

Dari hasil telaah data pada putaran kesatu dan kedua ternyata dapat ditarik kesimpulan, sebagai berikut : 
1. Dengan metode pembelajaran Inside Outside Circle, aktivitas belajar membaca teks Eksplanasi siswa kelas VIII F SMP Negeri 1 Mojoanyar Mojokerto dapat meningkat.

2. Dengan metode pembelajaran Inside Outside Circle ternyata kemampuan membaca teks Eksplanasi siswa kelas VIII-F SMP Negeri 1 Mojoanyar Mojokerto dapat meningkat. .

\section{Daftar Pustaka}

Burns, Paul C., Betty D., Roe, and Elinor P. Rose., (1994). Teaching Reading in Today's Elementary Schools. Boston: Hounghton., Mifflin

Djamarah, 2006, Kemampuan membaca Dan Kompetensi Guru, Surabaya, Usaha Nasional

Kartomihardjo, Suseno. (1999). Penggunaan Bahasa Dalam Masyarakat. Makalah Pada Pertemuan Ilmiah MU Regional Jawa Timur. Malang 20-21 Oktober

Mulyasa, 2005, Menjadi Guru Profesional Menciptakan Pembelajaran Kreatif Dan Menyenangkan, Bandung, Remaja Rodaskarya

Ngalimun, 2014, Strategi dan model pembelajaran, Yogyakarta, Aswaja Presindo

Silberman, Melvin L, 2004, Active Learning 101 Cara Belajar Siswa Aktif, Bandung, Nusamedia

Soedijarto, 2003, Model-model mengajar CBSA, Bandung, Sinar Baru

Sujana, 2003, Cara-Cara Belajar Siswa Aktif Dalam Proses Belajar Mengajar, Bandung, Sinar Baru

Suryabrata,S, 2004, Psikologi Kepribadian, Jakarta, CV Rajawali
Syah, Muhibbin, 2005, Psikologi Pendidikan Suatu Pendekatan Baru, Bandung, Rosdakarya

Tim Prima Pena, 2005, Kamus Besar Bahasa Indonesia, Jakarta, Gita Media Press

Winkel WS, 2007, Psikologi Pengajaran, Jakarta, Gramedia

Wiryodojoyo, Suwaryono. (2001). Membaca : Strategi Pengantar dan Tekniknya. Jakarta : Depdikbud

USMPn, Moh. Uzer, 2000, Menjadi Guru Profesional, Bandung, Remaja Rosdakarya , 2003, UU RI No.20 Tahun 2003 Tentang Sistem Pendidikan Nasional, Jakarta, Depdiknas RI 